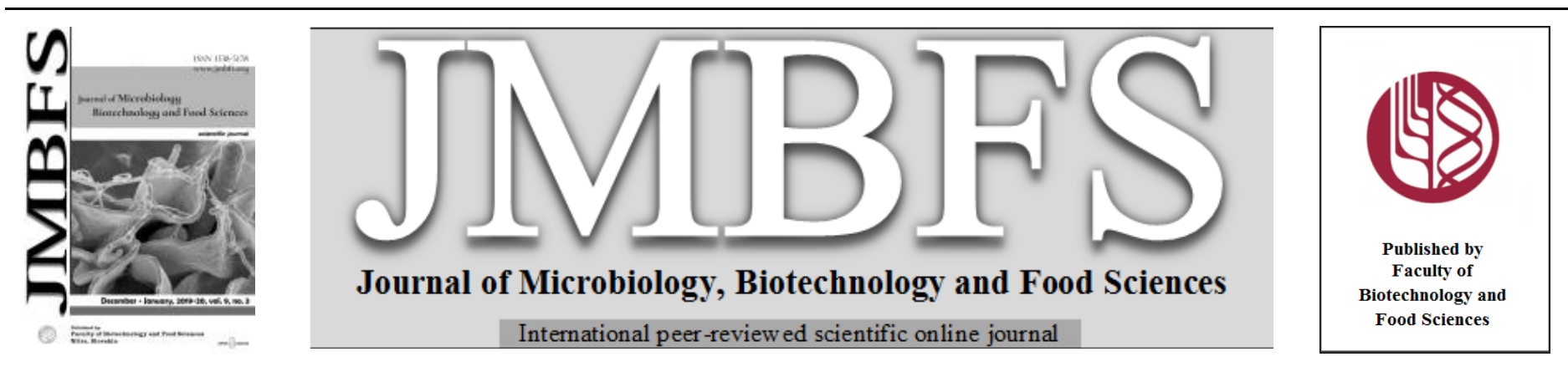

\title{
PROXIMATE, MINERAL AND FUNCTIONAL PROPERTIES OF TIGER NUT FLOUR EXTRACTED FROM DIFFERENT TIGER NUTS CULTIVARS
}

\author{
Nina G.Cl, Ogori A. $F^{2}$, , Ukeyima. $M^{1}$, Lukas Hleba ${ }^{3}$, Miroslava Císarová ${ }^{4}$,Eleonora Okuskhanova ${ }^{5}$, Stanislav Vlasov ${ }^{6}$, Natalya \\ Batishcheva ${ }^{6}$, Andrey Goncharov ${ }^{6}$, Mohammad Ali Shariati ${ }^{7,}$ *
}

$\operatorname{Address}(e s)$ :

${ }^{1}$ Department of Food Science and Technology, Federal University of Agriculture, Makurdi, Benue State, Nigeria.

${ }^{2}$ Department of Home Sciences, Faculty of Agriculture, Federal University, Gashua, P.M.B.1005 Gashua, Yobe State, Nigeria.

${ }^{3}$ Department of Microbiology, Faculty of Biotechnology and Food Sciences, Slovak University of Agriculture in Nitra, Nitra, Slovak Republic.

${ }^{4}$ University of SS. Cyril and Methodius, Department of Biology, Faculty of Natural Sciences, Nám. J. Herdu 2, SK-91701 Trnava, Slovak Republic

${ }^{5}$ Shakarim State University of Semey, Semey, Kazakhstan.

${ }^{6}$ K.G. Razumovsky Moscow State University of technologies and management (the First Cossack University), Moscow, Russia.

${ }^{7}$ Kazakh Research Institute of Processing and Food Industry (Semey Branch), Semey, Kazakhstan.

*Corresponding author: ogorifaraday@gmail.com, Shariatymohammadali@gmail.com

doi: 10.15414/jmbfs.2019/20.9.3.653-656

ARTICLE INFO

Received 13. 5. 2019

Revised 6. 6. 2019

Accepted 10. 6. 2019

Published 1. 12. 2019

Regular article

OPEN $\bigodot_{\text {ACCESS }}$

\begin{abstract}
Tiger nut flour extracted from (black, brown and yellow) cultivars using attrition milling process was investigated. Tiger nut flours labeled $\mathrm{Ab}, \mathrm{Bb}$ and $\mathrm{Cy}$ for black, brown and yellow cultivars were produced respectively. Proximate composition, mineral elements contents, functional properties of the tiger nut flours were determined. There was significant $(\mathrm{p}<0.05)$ difference between the moisture, ash, crude fat, crude fiber, crude protein and carbohydrate content of the flour samples which ranged 4.77-4.99\%, 1.95-2.05\%, $(5.62-$ $8.16 \%, 19.03-22.06 \%, 5.62-6.23 \%, 58.94-62.94 \%$ respectively. The least and the most moisture content of tiger nut were related to brown color $(4.47 \%)$ and black color $(4.99 \%)$ respectively. Flour crude protein value from brown Bb colored tiger nut flour $6.23 \%$ was higher than the black $6.28 \%$. There was also significance $(\mathrm{p}<0.05)$ differences in the bulk density, water and oil absorption capacity and foam capacity which ranged from $(0.76-0.79) \mathrm{g} / \mathrm{ml},(1.76-1.79) \mathrm{ml} / \mathrm{g},(1.43-1.79) \mathrm{ml} / \mathrm{g},(4.72-9.9 .0) \%$ among cultivars; However, flour from brown color had better swell ability index and water absorption capacity. The flours from black color sample indicated high values in oil absorption and foaming capacities. There were no significant $(\mathrm{p}<0.05)$ difference in the swelling index of the flour samples which ranged between $2.22-2.57 \mathrm{~g} / \mathrm{ml}$. The mineral content of the tiger nut flours differed $(\mathrm{p}<0.05)$ significantly. Flour from black color tiger nut had excellent mineralization, Zn (2.14), Ca (93.75), P (10.14), K (121.95), Na (105.6) and Fe (4.04). This work revealed that tiger nut flour is a potential source of food ingredient for supplementation, in particular, local cereal food for all age groups and could be an excellent source of raw material for our growing functional food industries.
\end{abstract}

Keywords: Tiger nut, Flour, Proximate, Mineral, Functional, Potentials

\section{INTRODUCTION}

Tiger nut (Cyperusesculentum) is a perennial grass-like plant with spheroid tubers, pale yellow cream kernel surrounded by a fibrous sheath. It is also known as yellow nut sedge, earth or ground almonds, "souchet" in French, "ermandeln" in German and "chufa" in Spanish (TTSL, 2005). Tiger nuts are edible, sweet, nutty, flavored tubers which contain protein, carbohydrate, sugars, and lots of oil and fiber $($ FAO, 2000). However, it has been a neglected crop in Nigeria due to the lack of knowledge on its production, utilization and nutritional value of it flour. Tiger nut could provide a functional flour basis for rural industries in Africa. It is an important food crop for certain tribes in Africa, often collected and eaten raw, baked as a vegetable, roasted or dried. It is mostly consumed raw as snack with good therapeutic quality (Moore, 2004). Milling process into flour can be applied to tiger nut processing to modify its appearance, develop its natural flavor, stimulate the digestive juices, make it easily digestible, increase in-vivo- bio-availability, destroy harmful microorganisms, improve its nutritional quality and prevent decomposition (Ndubuisi, 2009). There are mainly three varieties namely: black, brown and yellow, and only yellow and brown are readily available in the Nigerian markets. The yellow cultivar is preferred to all other varieties because of its inherent properties like its bigger size, attractive color and tourism body. The yellow cultivar also yields more milk, contains lower fat and with less anti-nutritional factors and polyphenols (Okafor $\boldsymbol{e t}$ al., 2003).
Tiger nut could help prevent heart problems, thrombosis and activate blood circulation; it is also responsible for preventing and treating urinary tract and bacterial infection and assist in reducing the risk of colon cancer when eaten (Adejuyitan et al. 2009). The edible flour obtained from the tuber could be superior and compares favorably with other tuber crops flours. It is considered as a very important food crop that has great potential in managing, preventing and eliminating malnutrition (macronutrient and micronutrient deficiencies) and could ameliorate food insecurity problems when applied as flour ingredients in food systems. Therefore, this study aims at characterizing different cultivar of tiger nut from the standpoints of functionality and chemical compositions.

\section{MATERIAL AND METHODS}

\section{Raw Materials}

Brown and yellow tiger nuts were purchased from North bank market Makurdi, while the black tiger nut was purchased fromVandelkya market, all in Benue State, Nigeria. They were taken to the Department of Agronomy, Federal University of Agriculture,Makurdi for identification.

\section{Tiger nut flour Production}

Tiger nut flour was produced following the method of Adejuyitan (2011) as shown in Figure 1.The samples were separately cleaned, washed and oven dried at $103^{\circ} \mathrm{C}$ for $1 \mathrm{hr}$ milled and sieved into flour. 

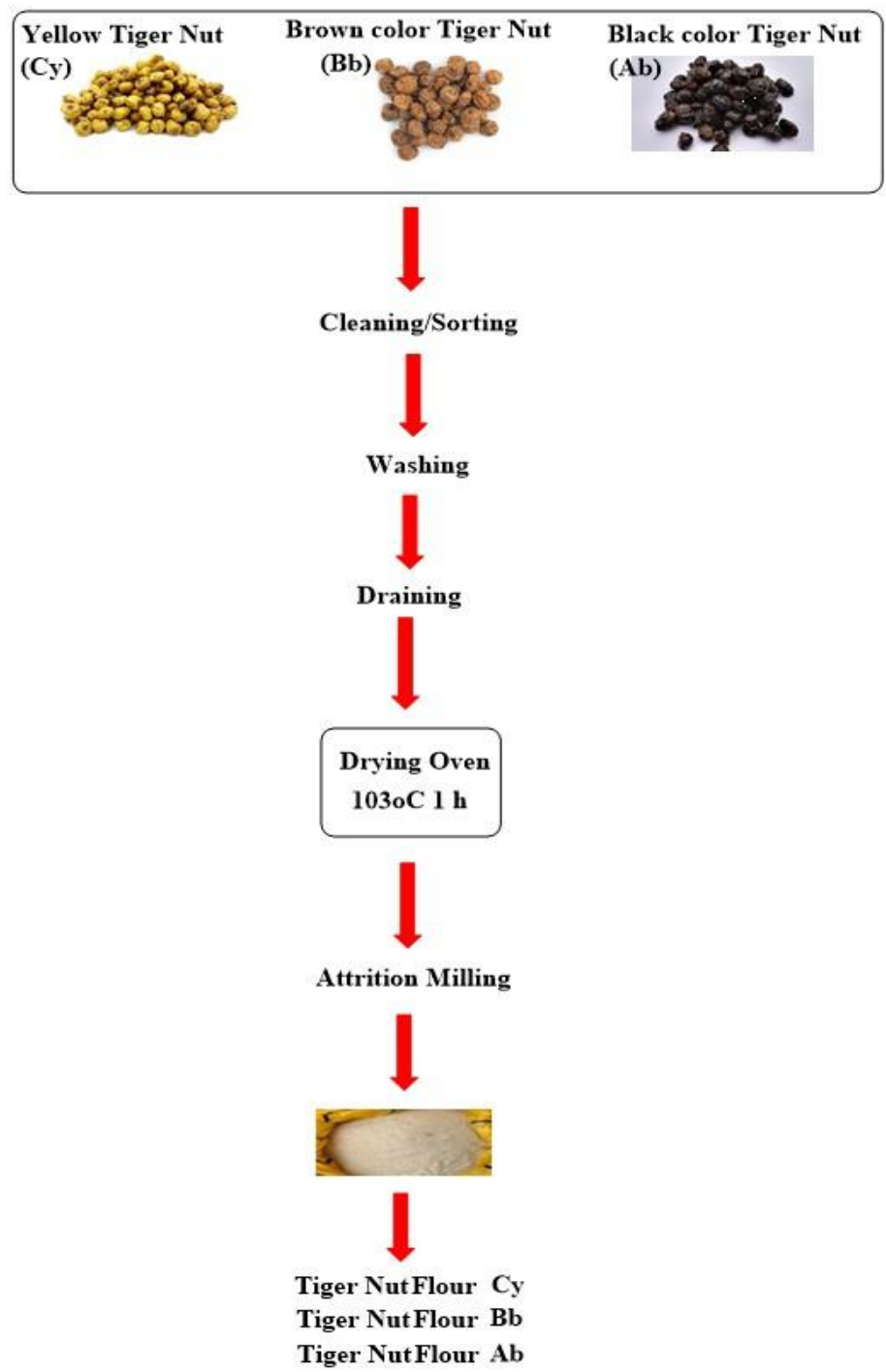

Figure 1 Flow chart for tiger nut flour Production (Adejuyitan, 2011)

Proximate Analysis of Tiger Nut Flour

Moisture, ash, fat, fiber and protein of the samples were determined according to standard methods of AOAC (2012) and Carbohydrate was determined by difference.

\section{Functional Properties of Tiger Nut Flour}

Bulk density, foaming capacity, water and oil absorption capacities of tiger nut flour and Swelling index of tiger nut flour (Oladele et al., 2007).

\section{Mineral Content of Tiger Nut Flour}

The Mineral content of each sample for sodium $(\mathrm{Na})$, potassium $(\mathrm{K})$, calcium $(\mathrm{Ca})$,iron $(\mathrm{Fe})$, magnesium $(\mathrm{Mg})$, zinc $(\mathrm{Zn})$, copper $(\mathrm{Cu})$ and phosphorus $(\mathrm{P})$. were analyzed using spectrophotometric method was used Samples were analyzed (AOAC, 2012).

\section{Statistical Analysis}

All experiment was conducted in duplicate and subjected to analysis of variance (ANOVA) using statistical package of Social Sciences (SPSS) version 20.0 Means separation was done using Duncan Multiple Range Test and significant difference was established at $\mathrm{p}<0.05$.

\section{RESULTS AND DISCUSSION}

Table 1 shows the proximate composition of tiger nut flours. There was significant $(\mathrm{p}<0.05)$ difference in the moisture, crude fat, crude fat and carbohydrate content of the flour sample while there was no significant $(p>0.05)$ difference in ash and crude protein content. The low moisture content observed in all the samples was in agreement with El-Naggar (2016) who reported moisture content to be below $10 \%$. Flours with low moisture content are good in terms of storability (Barber et al., 2017) without spoilage (Nwodo and Obinna, 2012) The crude fiber of the black cultivar was higher than the brown and yellow varieties. El-Naggar (2016) reported a fiber content of $6.5 \%$, the values obtained in this work are within this range. Tiger nut was observed to be high in dietary fiber content (15.47\%) as reported by Adel et al. (2015) which could be effective in the treatment and prevention of many diseases including colon cancer, coronary hearth diseases, obesity, diabetics and gastro intestinal disorders. The crude protein of the brown cultivar was higher than that of the black and yellow cultivar and this was within the range reported by Akubor and Badifu, (2004). The protein compares favorably with the value of $9.8 \%$ reported for wheat flour. The protein content was similar to the value reported by El-Naggar (2016) but was higher than the values observed by (Ogunlade $\boldsymbol{e t}$ al., 2015) who reported protein content to be 1.56 and 1.32 respectively; this could be due to difference in varieties. There was no significant $(\mathrm{p}<0.05)$ difference among the ash content of the flour samples. The ash content of the flour samples were higher than the values reported by Ndubuisi Linda, (2009) who reported lower ash content (0.70-1.53\%). According to Okoye and Ojobor (2016) the increase in ash content implies that the samples are good sources of mineral. There was significant difference $(\mathrm{p}<0.05)$ in fat content of the flour samples. The fat content (19.03 to $22.05 \%$ ) is relatively high when compared to pearl millet (7.6\%) and quinoa $(6.3 \%)$ (Oshodi et al., 1999), pigeon pea flour $(1.80 \%)$ (Okpala and Mammah, 2001) and wheat flour (3.10\%) (Akubor and Badifu, 2004) but low compared to some commonly consumed oil seeds in Nigeria; Pentaclethra macrophylla $(46.0 \%)$, Telfairia occidentalis $(49.2 \%)$ according to Oladele et al (2007). There was significant difference $(\mathrm{p}<0.05)$ between the carbohydrates content of the flour samples. The yellow cultivar had the highest carbohydrates content than the black and brown cultivar. The carbohydrate content in this work was higher than the values reported by El-Naggar (2016) and Adel et al. (2015) whose carbohydrates content was $47 \%$ and $48.12 \%$ respectively.

Table 1 Proximate Composition of Tiger Nut Flours

\begin{tabular}{lcccccc}
\hline Samples & Moisture \% & Ash \% & Crude fat \% & Crude fiber \% & Crude protein \% & CHO \% \\
\hline $\mathrm{Ab}$ & $4.99 \mathrm{a} \pm 0.09$ & $2.05 \mathrm{a} \pm 0.11$ & $19.79 \mathrm{~b} \pm 0.38$ & $8.16 \mathrm{a} \pm 0.13$ & $6.08 \mathrm{a} \pm 0.19$ & $58.92 \mathrm{~b} \pm 0.67$ \\
$\mathrm{Bb}$ & $4.47 \mathrm{~b} \pm 0.26$ & $2.03 \mathrm{a} \pm 0.17$ & $22.06 \mathrm{a} \pm 0.31$ & $6.04 \mathrm{~b} \pm 0.16$ & $6.23 \mathrm{a} \pm 0.17$ & $59.18 \mathrm{~b} \pm 0.46$ \\
$\mathrm{Cy}$ & $4.83 \mathrm{a} \pm 0.12$ & $1.95 \mathrm{a} \pm 0.96$ & $19.03 \mathrm{~b} \pm 0.18$ & $5.62 \mathrm{~b} \pm 0.16$ & $5.62 \mathrm{a} \pm 0.22$ & $62.94 \mathrm{a} \pm 0.23$ \\
\hline
\end{tabular}

Values are Means \pm standard deviation of duplicate determinations. Mean values down the column followed by different superscripts are significantly $(\mathrm{p}<0.05)$ different.

Key: Sample $\mathrm{Ab}=$ Black tiger nut, Sample $\mathrm{Bb}=$ Brown tiger nut, Sample $\mathrm{Cy}=$ Yellow tiger nut

\section{Mineral Compositions of Tiger nut Flours}

The mineral content of tiger nut flour is presented in table 2.The values of Potassium, sodium, copper, and calcium ranged between $110.70-121.95$ $\mathrm{mg} / 100 \mathrm{~g}, \quad 99.95-105.6 \mathrm{mg} / 100 \mathrm{~g}, \quad 0.20-0.50 \mathrm{mg} / 100 \mathrm{~g}$ and $84.05-93.75$ $\mathrm{mg} / 100 \mathrm{~g}$ respectively. The iron, magnesium, phosphorus and zinc content of the samples ranged between $3.03-4.04 \mathrm{mg} / 100 \mathrm{~g}, \quad 0.23-0.48 \mathrm{mg} / 100 \mathrm{~g}, \quad 2.10$ $6.03 \mathrm{mg} / 100 \mathrm{~g}, 6.89-10.14 \mathrm{mg} / 100 \mathrm{~g}$ and $1.67-2.14 \mathrm{mg} / 100 \mathrm{~g}$ respectively. The samples differed significantly $(\mathrm{p}<0.05)$ among the mineral elements.

Table 2 Mineral Composition of Tiger Nut Flours

\begin{tabular}{lccccccccc}
\hline Samples & $\mathbf{K}$ & $\mathbf{N a}$ & $\mathbf{C u}$ & $\mathbf{C a}$ & $\mathbf{F e}$ & $\mathbf{M n}$ & $\mathbf{M g}$ & $\mathbf{P}$ & $\mathbf{Z n}$ \\
\hline $\mathrm{Ab}$ & $121.95^{\mathrm{a}} \pm 0.06$ & $105.6^{\mathrm{a}} \pm 1.90$ & $0.50^{\mathrm{a}} \pm 0.01$ & $93.75^{\mathrm{a}} \pm 0.77$ & $4.04^{\mathrm{a}} \pm 0.01$ & $0.48^{\mathrm{a}} \pm 0.02$ & $6.03^{\mathrm{a}} \pm 0.03$ & $10.14^{\mathrm{a}} \pm 0.02$ & $2.14^{\mathrm{a}} \pm 0.01$ \\
$\mathrm{Bb}$ & $120.98^{\mathrm{b}} \pm 0.08$ & $99.95^{\mathrm{b}} \pm 0.07$ & $0.41^{\mathrm{b}} \pm 0.03$ & $91.19^{\mathrm{b}} \pm 0.54$ & $3.03^{\mathrm{c}} \pm 0.03$ & $0.36^{\mathrm{b}} \pm 0.01$ & $4.18^{\mathrm{b}} \pm 0.01$ & $8.98^{\mathrm{b}} \pm 0.01$ & $1.96^{\mathrm{b}} \pm 0.02$ \\
$\mathrm{Cy}$ & $110.70^{\mathrm{c}} \pm 0.14$ & $100.5^{\mathrm{b}} \pm 0.21$ & $0.20^{\mathrm{c}} \pm 0.01$ & $84.05^{\mathrm{c}} \pm 0.07$ & $3.55^{\mathrm{b}} \pm 0.06$ & $0.23^{\mathrm{c}} \pm 0.01$ & $2.10^{\mathrm{c}} \pm 0.01$ & $6.89^{\mathrm{c}} \pm 0.01$ & $1.67^{\mathrm{c}} \pm 0.02$ \\
\hline
\end{tabular}

Values are Means \pm standard deviation of duplicate determinations. Mean values down the column followed by different superscripts are significant (p $<0.05)$ different. Key: Sample Ab: Black tiger nut, Sample Bb: Brown tiger nut, Sample Cy: Yellow tiger 
There was significant $(\mathrm{p}<0.05)$ difference in all the samples. The potassium content of the black cultivar was higher than that of the brown and yellow cultivar. The potassium content as reported by Oladele et al., (2007) was higher than the values observed in this work. Potassium is needed for the regulation of fluid, muscle control and normal nerve function. Potassium aids nerve impulse transmission and it is a major cation of intracellular fluid. High potassium to low sodium ration of tiger nuts therefore, may be imperative in diet formulations for patients with high blood pressure and edema as well (Ndubuisi, 2009). There was significant $(\mathrm{p}<0.05)$ difference in the sodium contents of the samples. The black cultivar had the highest sodium content than the brown and yellow cultivar. There was significant $(\mathrm{p}<0.05)$ difference in the copper content of the samples. Copper aids in iron metabolism. It works with many antioxidants, enzymes especially those involved in protein metabolism and hormone synthesis Ndubuis (2009). The copper content of the black cultivar had the highest value than the brown and yellowcultivar.it was higher than the values reported by Oladele $\boldsymbol{e}$ al., (2007). There was also significant $(\mathrm{p}<0.05)$ difference in the calcium content of the samples. The black cultivar had the highest calcium content than the brown and yellow cultivar. Calcium aids in the formation of bones and plays a role in maintaining the working of the heart and muscles (Yusufu et al., 2015). The calcium content of this work was lower than the values reported by Oladele.et al. (2007). There was significant $(\mathrm{p}<0.05)$ difference in the iron content of the samples. The black cultivar had the highest iron content than the yellow and brown varieties. Iron is the functional component of haemoglobin and other key compounds used in respiration, immune function and cognitive developmen (Ndubuisi 2009). Iron deficiency negatively influences the normal defense systems against infection. It also serves as a carrier of oxygen to tissues within cells and is an integral part of important enzyme systems (FAO/WHO, 2001) According to Oladele et al. (2007), the iron content which ranged from 0.65 to 0.80 for yellow and brown cultivar respectively was lower than the values obtained in this work. High iron content of tiger nuts could contribute in preventing anaemia (Ndubuisi, 2009). There was significant $(\mathrm{P}<0.05)$ difference in the magnesse content of the samples. The black cultivar had the highes magnesse content than the brown and yellow cultivar. Oladele et al. (2007) reported a higher magnesse content than the values obtained in this work. There was significant $(\mathrm{p}<0.05)$ difference in the magnesium content of the samples. The magnesium content of the black cultivar was higher than the brown and yellow cultivar. Magnesium provides bone strength, aids enzyme, nerve and hear functions (Ndubuisi, 2009). According to Oladele et al., (2007), the magnesium content of tiger nut flour was higher than values obtained in this work. There was significant $(p<0.05)$ difference in the phosphorus content of the samples. The phosphorus content of the black cultivar was higher than the brown and yellow cultivar. Phosphorus enhances quick release of energy in the body and may combine with calcium for bone and teeth development (Ndubuisi, 2009). There was significant $(\mathrm{p}<0.05)$ difference in the zinc content of the samples. The zinc content of the black cultivar was higher than the brown and yellow cultivar. The zinc content in this work was higher than the values obtained by Oladele et al. (2007). Zinc is an integral part of hormones and more than nearly 100 different enzymes. Zinc is important in many metabolic reactions and may play an important role in immunity, alcohol metabolism, sexual development and reproduction (Ndubuisi, 2007). Deficiency can result in growth failure, enlarged spleen and liver (Barber et al., 2017).

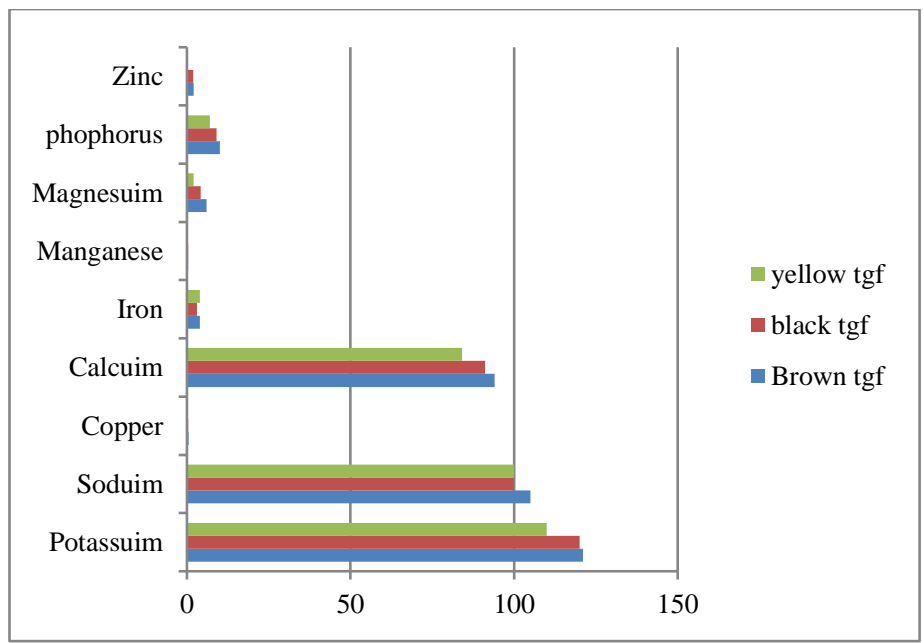

Figure 2 Level of macro and micro mineral in tiger nut flour cultivars

Key: Sample Ab: Black tiger nut, Sample Bb: Brown tiger nut, Sample Cy: Yellow tiger

\section{Functional Properties of Tiger Nut Flours}

Table 2 presents the functional properties of tiger nut flour. There was significant $(\mathrm{p}<0.05)$ difference in the bulk density, water and oil absorption capacity and foam capacity but no significant $(\mathrm{p}<0.05)$ difference exist in the swelling index of the sample. The bulk density of the flour samples ranged from $0.76-0.79$ $\mathrm{g} / \mathrm{ml}$, the bulk density of sample $\mathrm{C}$ (yellow cultivar) had the highest value followed by sample A (black cultivar) while sample B (brown cultivar) had the least value. The swelling index ranged from $2.22-2.57 \mathrm{~g} / \mathrm{ml}$, the swelling capacity of sample B was significantly $(\mathrm{p}<0.05)$ different from that of sample A and C. The water absorption capacity ranged from $1.39-1.74 \mathrm{ml} / \mathrm{g}$, the water absorption capacity of sample B was significantly $(\mathrm{p}<0.05)$ different from that of sample of $\mathrm{A}$ and $\mathrm{C}$. The oil absorption capacity ranged from $1.43-1.79 \mathrm{ml} / \mathrm{g}$. The oil absorption capacity of sample A had the highest value followed by sample B while sample $\mathrm{C}$ had the least value. The foam capacity ranged from $4.72-9.90 \%$, the foam capacity of sample A was significantly $(\mathrm{p}<0.05)$ different from sample $\mathrm{B}$ and $\mathrm{C}$.

The bulk density of the sample C (yellow cultivar) was higher than those of sample A (black cultivar) and B (brown cultivar). The bulk density in this work were higher than the values reported by Oladele.et al. (2007) and Akubor et al. (2004) whose values were $0.65 \mathrm{~g} / \mathrm{cm}^{3}$ and $0.71 \mathrm{~g} / \mathrm{cm}^{3}$ reported for wheat flour. Nutritionally, low bulk density promotes digestibility of foods especially in children with immature digestive systems while high bulk density decreases the caloric and nutrient intake of children resulting in growth faltering (Olaitan $\boldsymbol{e}$ al., 2014). Low bulk density also implies that the product can easily be packaged for economic use. According to Nnam (2001) low bulk density has nutritional and economic significance as more of the products can be eaten thus leading to high energy and nutritional density. There was no significant $(\mathrm{p}<0.05)$ difference between the swelling capacity of the tiger nut flour samples from different varieties. The swelling capacity depends on the size of particles, cultivar of crop, processing unit operations or methods (Chandra et al., 2015). Swelling index determines the amount of water food samples would absorb and the degree of swelling within a given time. The swelling capacity of sample B (brown cultivar) was higher than those of sample A(black) and $\mathrm{C}$ (yellow cultivar) as shown in table 4.2, it was higher than the swelling capacity as reported by Oladele et al. (2007) whose values were 2.40 and $2.10 \mathrm{~g} / \mathrm{cm}^{3}$ for yellow and brown cultivars respectively. There was significant $(\mathrm{p}<0.05)$ difference between the water absorption capacity of the flour samples from different cultivars. Water absorption capacity gives an index of water absorbed or retained. The water absorption capacity also indicates how cohesive a product is (Osungbaro $\boldsymbol{e t}$ al . 2010). High water absorption is of a disadvantage as it reduces the absorption of nutrients (Olaitan et al., 2014). According to Oyarekua and Adeyeye (2009) water absorption capacity is desirable for improving mouthfeel and reducing the viscosity of products. The variation in water absorption capacity of the composite flour may also be due to the concentration of protein, degree of interaction with water and conformational characteristics (Menon et al., 2015). The water absorption capacity of sample B (brown cultivar) was higher than sample A (black cultivar) and $\mathrm{C}$ (yellow cultivar). it was higher than the values reported by Oladele et al. (2007) whose values were 1.37 and $1.26 \mathrm{ml} / \mathrm{g}$ for yellow and brown cultivar respectively. There was significant difference $(\mathrm{p}<0.05)$ between the oil absorption capacity of the tiger nut flour samples of different varieties. The oil absorption capacity of sample B was higher than sample A and C, it was higher than the values as reported by Oladele et al. (2007) whose values were 1.13 and $1.03 \mathrm{ml} / \mathrm{g}$ for yellow and brown cultivar respectively, it was also higher than the values reported Salau et al. (2012) whose values were $0.88 \mathrm{~g} / \mathrm{cm}^{3}$ and $0.91 \mathrm{~g} / \mathrm{cm}^{3}$ respectively for yellow and brown cultivar Oil absorption capacity is the ability of the flour protein to physically bind fat by capillary attraction and it is of great importance since fat acts as flavor retainer and also increase the mouth feel of foods respectively (Onimawo and Akubor, 2005). The lower oil absorption capacity of tiger nut flour might be due to low hydrophobic proteins which show superior binding of lipids Oladele et al. (2007). There was significant difference $(p<0.05)$ between the foam capacity of the tiger nut flour samples. The foam capacity of sample A was higher than sample C and B. it was lower than the values observed by Oladele et al. (2007) whose values were 10.28 and $11.07 \%$ respectively. 
Table 3 Functional Properties of Tiger Nut Flours

\begin{tabular}{llllll}
\hline Samples & Bulk density $(\mathrm{g} / \mathbf{m l})$ & Swelling index $(\mathrm{g} / \mathbf{m l})$ & Water absorption $(\mathrm{g} / \mathbf{m l})$ & $\begin{array}{l}\text { Oil absorption } \\
(\mathbf{m L} / \mathbf{g})\end{array}$ & Foam capacity \% \\
\hline $\mathrm{Ab}$ & $0.77^{\mathrm{ab}} \pm 0.01$ & $2.22^{\mathrm{a}} \pm 0.11$ & $1.65^{\mathrm{b}} \pm 0.03$ & $1.79^{\mathrm{a}} \pm 0.01$ & $9.90^{\mathrm{a}} \pm 1.40$ \\
$\mathrm{Bb}$ & $0.76^{\mathrm{b}} \pm 0.01$ & $2.57^{\mathrm{a}} \pm 0.19$ & $1.74^{\mathrm{a}} \pm 0.05$ & $1.75^{\mathrm{a}} \pm 0.02$ & $4.72^{\mathrm{c}} \pm 1.34$ \\
$\mathrm{Cy}$ & $0.79^{\mathrm{a}} \pm 0.01$ & $2.33^{\mathrm{a}} \pm 0.00$ & $1.39^{\mathrm{c}} \pm 0.01$ & $1.43^{\mathrm{b}} \pm 0.04$ & $6.00^{\mathrm{b}} \pm 2.82$ \\
\hline
\end{tabular}

Values are Means \pm standard deviation of duplicate determinations. Mean values down the column followed by different superscripts are significantly $(\mathrm{p} \leq 0.05)$ different. Key: Sample A= Black tiger nut, Sample B= Brown tiger nut, Sample C= Yellow tiger nut

\section{CONCLUSION}

The result of the study revealed information on the nutritional composition, mineral and functional properties of tiger nut flour from different cultivars. Tiger nut flour is a rich source of some useful mineral elements such as potassium, phosphorus, zinc, sodium and calcium which are necessary for body growth and development. The results of this study have provided much justification for the use of tiger nut flour in food products. The high content of mineral and protein values as well as fiber content makes tiger nut flour a very nutritious and health potential flour. Thus tiger nut flour should be developed into a commercial product for use in food products. Tiger nut flour can play important roles in providing food security, enhancing livelihoods, improves nutritional status and social wellbeing of vulnerable groups. Tiger nuts flour and its products could thus, go a long way in aiding to alleviate problems of malnutrition and reduce food security.

\section{REFERENCES}

Adel, A. A. M., Awad, A. M., Mohamed, H. H. \& Iryna, S. (2015). Chemica composition, physicochemical properties and fatty acid profile of Tiger Nut (Cyperus esculentus $\mathrm{L}$ ) seed oil as affected by different preparation methods. Food Research Journal, 22(5), 1931-1938.

Adejuyitan, J. A, Otunola, E. T., Akande, E. A., Bolarinwa, I. F., \& Oladokun, F. M. (2009). Some physicochemical properties of flour obtained from fermentation of tiger nut (Cyperus esculentus) sourced from a market in Ogbomoso, Nigeria. African Journal of Food Science, 3(2), 51-55.

Adeyijutan, J.A. (2011). Tiger nut processing: its food use and health benefits. American journal of food technology, 6(3),197 -201. https://doi.org/10.3923/ajft.2011.197.201.

Akubor, P. I, \& Badifu G.I.O. (2004). Chemical composition, functional properties and baking potential of African breadfruit kernel and wheat flour blends. International Journal of Food Science and Technology, 39, 223-229. https://doi.org/10.1046/j.0950-5423.2003.00768.x.

AOAC. (2010). Official Methods of Analysis: Association of Official analytical Chemists, Washington, DC. USA.

AOAC (2012). Official Methods of Analysis. 18th Ed. American Association of Analytical Chemists, Inc., Washington.

Barber, L. I., Obinna-Echem P. C., \& Ogburia, E. M. (2017). Proximate composition micronutrient and sensory properties of complementary food formulated from fermented maize, soybeans and carrot flours. Sky Journal of Food Science, 6(3), 33-39.

Chandra, S., Singh, S., \& Kumari, D. (2015). Evaluation of functional properties of composite flours and sensorial attributes of composite flour biscuits. Journal of Food Science Technology, 52(6), 3681-3688. https://doi.org/10.1007/s13197014-1427-2.

El-Naggar, E. A. (2016). Physicochemical Characteristics of Tiger Nut Tuber (Cyperus esculentus Lam) Oil. Middle East Journal of Applied Sciences, 6, 1003 1011.

FAO. (2000). Human vitamin and mineral requirements FAO/WHO expert consultation on human vitamin and mineral requirement. 1-286.

Menon, L., Majumdar, S. D., \& Ravi, U. (2015). Development and analysis of composite flour bread. Journal of Food Science and Technology, 52(7), 41564165. https://doi.org/10.1007/s13197-014-1466-8

Moore, M. (2004) Documents Prepared for Bottlegreen for the Product Tiger White: www.tigerwhitedrinks.com Copyright Miam Ltd. 1-22.

Ndubuisi, Linda Chinenyenwa (2009). Evaluation of food potentials of tiger nut tubers (cyperus esculentus) and its products (milk, coffee and wine). NDUBUISI, LINDA CHINENYENWA PG/M.SC/03/34134.

Nnam, N. M. (2001). Chemical, sensory and rheological properties of porridges from processed Sorghum (Sorghum bicolor), Bambara groundnut (Vigna subterranea L. Verdc) and Sweet potato (Ipomoea batatas) flours. Plant Foods for Human Nutrition, 56, 251-264.

Nwoodo S. C., \& Obinna, C.N. (2012). Proximate analysis of Sphenostylis stenocarpa and Voandzeia subterranean consumed in Southeastern Nigeria. Journal of Agricultural biotechnology and Sustainable Development, 4(1), 1-6. https://doi.org/10.5897/jabsd11.012.

Ogunlade, I., Adeyemi Bilikis, A., \& Aluko Olanrewaju, G. (2015). Chemical compositions, antioxidant capacity of tigernut (cyperus esculentus) and potential health benefits. European Scientific Journal, 217-224.
Olaitan, N. I., Eke, M. O., \& Uja, E. M. (2014). Quality Evaluation of Complementary Food Formulated from Moringa Oleifera Leaf Powder and Pearl Millet (Pennisetum glaucum) Flour. The International Journal of Engineering and Science, 3(11), 59-63.

Okafor, J. N. C., Mordi, J. I., Ozumba, A. U., Solomon, H.M., \& Olatunji, O (2003). Preliminary studies on the characterization of contaminants in tiger nut (Yellow variety). In Proceedings of 27th annual Nigerian Institute of Food Science and Technology (NIFST) conference, 210-211.

Okoye, J. I., \& Ojobor, C. C. (2016). Proximate composition, energy content and sensory properties of complementary foods produced from blends of sorghum and African yam bean flour. International Journal of Scientific and technology Research, 5(7), 274-277.

Okpala, L. C., \& Mammah, E. N. (2001). Functional properties of raw and processed pigeon pea (Cajanus cajan) flour. International Journal of Food $\begin{array}{llll}\text { Science } \quad \text { and } & \text { Nutrition, } & \text { 343-346. }\end{array}$ https://doi.org/10.1080/09637480120057549.

Oladele A. K., \& Aina, J. O. (2007). Chemical composition and functional properties flour produced from two varieties of tiger nut (Cyperus esculentus). African Journal of Biotechnology, 6(21), 2473-2476. https://doi.org/10.5897/ajb2007.000-2391.

Oshodi A.A, Ekperigin M. M. (1989). Functional properties of Pigeon Pea (Cajanus cajan) flour. Food Chemistry, 34, 187-191. https://doi.org/10.1016/0308-8146(89)90139-8.

Osungbaro, T. O., Jimoh, D., \& Osundeyi, E. (2010). Functional and pasting properties of composite Cassava-Sorghum flour meals. Agriculture and Biology Journal of North America, 1(4), 715 720. https://doi.org/10.5251/abina.2010.1.5.903.908

Salau, R. B, Ndamitso, M. M., Paiko Y.B., Jacob, J. O., Jolayemi O. O., \& Mustapha, S. (2012). Assesment of the proximate composition, food functionality and oil characterization of mixed varieties of cyperus esculentus (Tiger nut) rhizome flour. Continental Journal of Food Science and technology, 6(2), $13-$ 19.

TTSL (2005) Tigernuts. Chufas. Souchet. Ermandeln. Pois Sucrés: Tigernut Traders, S.L. Export. www.tigernut.com; http:// www.tigernut.com/product3.htm 